\title{
Growth and Yield Response of Rodent Tuber (Typhonium flagelliforme (Lodd.) Blume) under Different Light Intensities and Concentrations of Paclobutrazol
}

Author

Affiliation
Noorwitri Utami*, Lukita Devy, Arief Arianto

Agency for the Assessment and Application of Technology (BPPT)

LAPTIAB, Building 612, Kawasan Puspiptek Serpong, Tangerang Selatan 15314, Indonesia

\section{Keywords \\ O light intensity \\ $\rightarrow$ retardant \\ $\rightarrow$ tuber yield}

Received 7 September 2015

Revised 22 June 2016

Accepted 5 December 2016

*Corresponding author Noorwitri Utami Agency for the Assessment and Application of Technology (BPPT)

LAPTIAB, Building 612, Kawasan Puspiptek Serpong, Tangerang Selatan 15314

Email:

noorwitri.utami@bppt.go.id

\section{ABSTRACT}

Rodent tuber (Typhonium flagelliforme (Lodd) Blume) is one of the medicinal plants used for anticancer treatment, but the information on the cultivation of the plant is limited. The objectives of this research was to study the effect of light intensity and concentration level of paclobutrazol on growth and yield of rodent tuber. This research was conducted at Puspiptek Serpong, Tangerang Selatan, Indonesia. This experiment arranged in a split plot design with three replications. The main plot is light intensity (35, 55 , and $100 \%)$. The sub plot is concentration level of paclobutrazol $(0,50,100$, and 150 ppm). Paclobutrazol applied as soil drench at one month after planting. In each application $500 \mathrm{ml}$ solution was used. Variables observed consisted of plant height, number of leaves, leaf length, leaf width, leaf and tuber fresh weight; and leaf and tuber dry weight. Data were analyzed using analysis of variance and Duncan Multiple Range test at $5 \%$. The result showed that interaction between light intensity and paclobutrazol affected the whole observed variable. Dry weight of tuber under 35\% light intensity was lower than those in other light intensity for all treatments of paclobutrazol. Full sunlight intensity showed better dry weight in all treatments of paclobutrazol. However the dry weight decreasing significantly at $150 \mathrm{ppm}$ paclobutrazol, but still higher than those in $35 \%$ light intensity. Therefore, rodent tuber is better cultivated under full sunlight and $55 \%$ light intensity with 100 ppm paclobutrazol.

\section{INTRODUCTION}

Cancer has become one of the deadliest disease in the world. Rodent tuber (Typhonium flagelliforme (Lodd) Blume) is one of traditional medicine used to combat cancer. Some research showed that rodent tuber extract has cytotoxic effect to cervix cancer cell (HeLa cells) (Da'i et al. 2007) and breast cancer cell (Putra et al. 2011). Rodent tuber is also used for cough and asthma (Zhong et al. 2001).

Every part of the rodent tuber, such as leaves, stem, tuber or root contains anticancer metabolites (Choo et al. 2011). Bioactive compounds in rodent tuber are flavonoid (Yunahara et al. 2012), alkaloid (Nobakht et al. 2010), sterol (Lai et al. 2010), saponin (Syahid 2008), cerebroside and glycoside (Huang et al. 2004). 
Photosynthesis limited by environmental factors such as water, $\mathrm{CO}_{2}$, light, temperature (Flexas et al. 2006) and growth retardant (Tanis et al. 2015). When the photosynthetic activity gripped by stress, plant growth and tuber formation (Ghosh et al. 2002) will be disrupted.

Geng et al. (2013) stated that reduced light intensity would increase chlorophyll content specifically chlorophyll b, decreased photosynthesis rate and crop production. Full light intensity tends to increase crop yield and tuber formation.

Paclobutrazol is a retardant which its active compound (triazole) could inhibit gibberellin biosynthesis. Paclobutrazol application could decrease stem and branch growth as well as increase abscisic acid and chlorophyll content (Chaney 2005). Some research showed that the application of paclobutrazol is able to increase tuber yield. Sambeka et al. (2012) reported that paclobutrazol $125 \mathrm{ppm}$ sprayed at 6 Weeks After Planting (WAP) could increase tuber yield per plant and per plot. Kozak (2002) also reported that Gloriosa rothschildiana shoot cultured in Murashige and Skoog (MS) medium supplemented by sucrose and paclobutrazol could induced and increased tuber formation.

The information of rodent tuber cultivation is still limited. Therefore, this research was conducted to study the sunlight intensity and paclobutrazol application to the growth and yield of rodent tuber.

\section{METHODS}

Research was conducted at Experimental Field of Center for Agricultural Production Technology - BPPT, Puspiptek Serpong, Banten (67 m above sea level). Split plot design with three replications was used in the experiment. The main plot is light intensity $(35,55$ and $100 \%)$ and the sub plot is paclobutrazol concentration (0, 50, 100 and $150 \mathrm{ppm})$. Each experimental unit consisted of three polybags and each of them is planted with one rodent tuber plant.

Seedling derived from tuber shoot. Only tubers with good quality are used as the source which were compact, free from defect, pest and disease. Tubers are cleaned under tap water and put in rice hull medium in a sunlight free room. Watering was conducted regularly. New shoots emerged at 2 WAP. Tuber with one shoot are cut and planted in each polybag. Plant media used are soil and manure (1:1) in a $40-\mathrm{cm}$ diameter polybag. Application of paclobutrazol conducted with soil drench and foliar spray at one Months After Planting (MAP).

Vegetative variables (plant height; leaves number, length and width) were observed every two weeks. Harvesting was conducted at 3 MAP. Yield variables consisted of leaves and tuber fresh and dry weight. Data analyzed by using Analysis of Variance (Anova). Duncan Multiple Range Test was conducted for mean separation (Gomez \& Gomez 1995).

\section{RESULT AND DISCUSSIONS}

Plant growth is affected by nutrition availability, light and plant growth regulator (Gardner et al. 1991). Result showed that there is interaction between light intensity and paclobutrazol concentration to rodent tuber growth and yield.

\section{Plant Height}

Plant height of rodent tuber was affected by light intensity and paclobutrazol concentration. Plant height correlated linearly with light intensity. It was shown that the height growth of rodent tuber under low sunlight intensity was relatively higher than those under full light intensity. Shading stimulated the height growth of rodent tuber to obtain the sunlight. Similar result was reported on taro (Djukri 2003). However, paclobutrazol concentration showed opposite trend (Table 1). This was also reported on sweet potato (Sunarlim et al. 2000). According to Cathey (1975) and Clifford \& Lenton (1979), paclobutrazol act as antigibberellin which could inhibit cell and sub apical meristem elongation which shorten the plant length.

\section{Leaves Number}

Light intensity and paclobutrazol concentration significantly affected leaves number. Light has important role in photosynthesis and respiration. Gardner et al. (1991) wrote that low light intensity induced the leaves surface to accept low light intensity. Under shaded condition, leaves number are more than those under unshaded area (Table 1). This might be caused by plant effort to catch more sunlight with more leaves number.

\section{Leaves Length and Width}

Leaves length and width were increasing with the decrease of light intensity. However, the higher paclobutrazol concentration caused less leaves length and width (Table 2). Salisbury \& Ross (1992) explained 
Table 1. Effect of interaction between light intensity and paclobutrazol concentrations to plant height and leaves number of rodent tuber

\begin{tabular}{|c|c|c|c|c|c|c|c|c|c|}
\hline \multirow{3}{*}{$\begin{array}{c}\text { Light } \\
\text { intensity } \\
(\%)\end{array}$} & \multirow{3}{*}{$\begin{array}{l}\text { Paclobutrazol } \\
\text { (ppm) }\end{array}$} & \multicolumn{4}{|c|}{ Leaves length (cm) } & \multicolumn{4}{|c|}{ Leaves width (cm) } \\
\hline & & \multicolumn{4}{|c|}{ Weeks After Planting (WAP) } & \multicolumn{4}{|c|}{ Weeks After Planting (WAP) } \\
\hline & & 6 & 8 & 10 & 12 & 6 & 8 & 10 & 12 \\
\hline \multirow{4}{*}{35} & 0 & $24.44^{\mathrm{ab}}$ & $30.11^{\mathrm{a}}$ & $30.11^{\mathrm{ab}}$ & $33.11^{\mathrm{a}}$ & $9.34^{b}$ & $14.89^{\mathrm{a}}$ & $20.33^{\mathrm{ab}}$ & $37.78^{\mathrm{ab}}$ \\
\hline & 50 & $26.78^{\mathrm{a}}$ & $31.77^{\mathrm{a}}$ & $30.56^{\mathrm{ab}}$ & $21.00^{b}$ & $8.89^{b}$ & $12.33^{\mathrm{abc}}$ & $15.67^{\mathrm{ab}}$ & $27.45^{\mathrm{bcd}}$ \\
\hline & 100 & $27.44^{\mathrm{a}}$ & $29.22^{\mathrm{a}}$ & $28.67^{\mathrm{ab}}$ & $19.77^{\mathrm{bc}}$ & $16.33^{\mathrm{a}}$ & $13.78^{\mathrm{ab}}$ & $16.88^{\mathrm{ab}}$ & $24.00^{c d}$ \\
\hline & 150 & $25.78^{\mathrm{a}}$ & $29.67^{\mathrm{a}}$ & $27.00^{\mathrm{ab}}$ & $14.67^{\mathrm{de}}$ & $9.56^{b}$ & $14.00^{\mathrm{ab}}$ & $12.00^{\mathrm{cd}}$ & $16.66^{\mathrm{de}}$ \\
\hline \multirow{4}{*}{55} & 0 & $24.78^{\mathrm{ab}}$ & $32.56^{\mathrm{a}}$ & $33.00^{\mathrm{a}}$ & $34.89^{\mathrm{a}}$ & $7.55^{b}$ & $15.11^{\mathrm{a}}$ & $22.00^{\mathrm{a}}$ & $42.89^{a}$ \\
\hline & 50 & $24.22^{\mathrm{ab}}$ & $29.55^{\mathrm{a}}$ & $27.78^{\mathrm{ab}}$ & $18.67^{\mathrm{bcd}}$ & $8.33^{b}$ & $16.00^{\mathrm{a}}$ & $21.22^{\mathrm{ab}}$ & $31.33^{b c}$ \\
\hline & 100 & $22.78^{a b}$ & $28.22^{\mathrm{a}}$ & $28.56^{\mathrm{ab}}$ & $16.00^{\text {cde }}$ & $6.89^{b}$ & $11.56^{\mathrm{abcd}}$ & $20.45^{a b}$ & $25.11^{\text {cd }}$ \\
\hline & 150 & $21.00^{b}$ & $26.44^{\mathrm{a}}$ & $24.22^{b}$ & $13.67^{e}$ & $7.45^{b}$ & $10.55^{\mathrm{abcd}}$ & $12.78^{\mathrm{abc}}$ & $17.22^{\mathrm{de}}$ \\
\hline \multirow{4}{*}{100} & 0 & $8.33^{c}$ & $8.22^{b}$ & $5.33^{c}$ & $11.88^{\mathrm{e}}$ & $5.22^{b}$ & $5.78^{\text {cd }}$ & $4.33^{c d}$ & $17.89^{\mathrm{de}}$ \\
\hline & 50 & $7.67^{c}$ & $7.77^{b}$ & $3.11^{\mathrm{c}}$ & $4.22 f$ & $4.33^{b}$ & $4.78^{d}$ & $3.00^{d}$ & $8.33^{\mathrm{e}}$ \\
\hline & 100 & $9.22^{c}$ & $9.05^{b}$ & $4.72^{c}$ & $4.89 f$ & $7.72^{b}$ & $5.78^{\mathrm{cd}}$ & $4.94^{\mathrm{cd}}$ & $9.83^{\mathrm{e}}$ \\
\hline & 150 & $9.17^{c}$ & $10.94^{b}$ & $5.72^{c}$ & $6.22 f$ & $5.39^{b}$ & $7.83^{\mathrm{bcd}}$ & $6.28^{\mathrm{cd}}$ & $12.23^{\mathrm{e}}$ \\
\hline
\end{tabular}

Note: Means followed by the same letter at the same column is not significantly different according to Duncan Multiple Range Test 5\%.

that low sunlight intensity will decreased leaves chlorophyll content and finally decreased photosynthesis rate. Under shaded condition, leaf area is increasing.

Paclobutrazol as retardant inhibited gibberellin production. Tekalign \& Hammes (2005) stated that gibberellin increased cell division and accelerate cell growth. Therefore, higher paclobutrazol application will decreased cell division in leaf meristem which finally will decreased leaves length and width.

\section{Leaves Fresh Weight}

Leaves fresh weight under 35\% light intensity were lower in all paclobutrazol concentration (Fig. 1c). Leaves fresh weight under $55 \%$ light intensity were increasing in $100 \mathrm{ppm}$ and $150 \mathrm{ppm}$ paclobutrazol. Leaves fresh weight under full light intensity were increasing with the increase of paclobutrazol up to 100 ppm and then decreasing at $150 \mathrm{ppm}$.

\section{Leaves Dry Weight}

Leaves dry weight under $35 \%$ light intensity in all paclobutrazol treatment is lower than those under $55 \%$ and $100 \%$. Leaves dry weight under full light intensity were increasing with the increase of paclobutrazol up to 100 ppm (Fig. 1d). Esmaielpour et al. (2011) stated that the dry weight of potato leaves increased with the increased concentrations of paclobutrazol.

\section{Tuber Fresh Weight}

Rodent tuber is potential for inhibiting breast cancer cell (MCF-7 cell) growth (Widowati \& Mudahar 2009). The tuber extract showed more effective inhibition than leaf extract (Putra et al. 2012). Rodent tuber fresh weight under all light intensity showed the highest result in 100 ppm paclobutrazol (Fig. 1a).

In photosynthesis, the light is converted into chemical energy in the form of ATP and NADPH which in turn used as energy for changing carbon dioxide into sugars and starches in dark reaction and for the distribution of photosynthate from leaves into other plant organs that have economic value (Sinclair \& Muchow 1999). Decreasing tuber fresh weight is possible due to the decreasing photosynthesis rate which resulted in the reduction of photosynthate.

\section{Tuber Dry Weight}

Tuber dry weight under $35 \%$ light intensity in all paclobutrazol treatment were lower than those under $55 \%$ and $100 \%$ light intensity. Under 55\% light 
Table 2. Effect of interaction between light intensity and paclobutrazol concentrations to leaves length and width of rodent tuber

\begin{tabular}{cccccccccc}
\hline \multirow{2}{*}{$\begin{array}{c}\text { Light } \\
\text { intensity } \\
(\%)\end{array}$} & $\begin{array}{c}\text { Paclobutrazol } \\
(\mathrm{ppm})\end{array}$ & \multicolumn{3}{c}{ Leaves length (cm) } & \multicolumn{3}{c}{ Leaves width (cm) } \\
\cline { 2 - 9 } & & \multicolumn{3}{c}{ Weeks After Planting (WAP) } & \multicolumn{3}{c}{ Weeks After Planting (WAP) } \\
\cline { 2 - 9 } & 0 & 8 & 10 & 12 & 6 & 8 & 10 & 12 \\
\hline \multirow{3}{*}{35} & 50 & $4.89^{\mathrm{a}}$ & $6.00^{\mathrm{ab}}$ & $5.78^{\mathrm{a}}$ & $6.11^{\mathrm{a}}$ & $10.11^{\mathrm{a}}$ & $11.78^{\mathrm{a}}$ & $12.11^{\mathrm{ab}}$ & $12.33^{\mathrm{a}}$ \\
& 100 & $5.50^{\mathrm{a}}$ & $6.22^{\mathrm{a}}$ & $6.11^{\mathrm{a}}$ & $6.33^{\mathrm{a}}$ & $11.45^{\mathrm{a}}$ & $12.44^{\mathrm{a}}$ & $12.56^{\mathrm{ab}}$ & $9.89^{\mathrm{b}}$ \\
& 150 & $5.55^{\mathrm{a}}$ & $5.33^{\mathrm{ab}}$ & $5.78^{\mathrm{a}}$ & $5.78^{\mathrm{a}}$ & $11.45^{\mathrm{a}}$ & $11.11^{\mathrm{a}}$ & $10.89^{\mathrm{b}}$ & $9.67^{\mathrm{b}}$ \\
& $5.55^{\mathrm{a}}$ & $5.67^{\mathrm{ab}}$ & $5.22^{\mathrm{a}}$ & $4.11^{\mathrm{cd}}$ & $10.89^{\mathrm{a}}$ & $11.89^{\mathrm{a}}$ & $10.67^{\mathrm{b}}$ & $7.67^{\mathrm{bc}}$ \\
\hline \multirow{3}{*}{55} & $5.00^{\mathrm{a}}$ & $5.89^{\mathrm{ab}}$ & $6.16^{\mathrm{a}}$ & $6.45^{\mathrm{a}}$ & $10.56^{\mathrm{a}}$ & $13.11^{\mathrm{a}}$ & $14.00^{\mathrm{a}}$ & $13.56^{\mathrm{a}}$ \\
& 50 & $4.61^{\mathrm{a}}$ & $5.45^{\mathrm{ab}}$ & $5.50^{\mathrm{a}}$ & $5.33^{\mathrm{ab}}$ & $10.44^{\mathrm{a}}$ & $11.33^{\mathrm{a}}$ & $11.56^{\mathrm{ab}}$ & $9.56^{\mathrm{b}}$ \\
& 100 & $5.06^{\mathrm{a}}$ & $5.67^{\mathrm{ab}}$ & $5.61^{\mathrm{a}}$ & $5.56^{\mathrm{ab}}$ & $10.45^{\mathrm{a}}$ & $12.11^{\mathrm{a}}$ & $12.11^{\mathrm{ab}}$ & $8.33^{\mathrm{bc}}$ \\
& 150 & $4.44^{\mathrm{a}}$ & $4.89^{\mathrm{b}}$ & $5.00^{\mathrm{a}}$ & $4.45^{\mathrm{bc}}$ & $9.56^{\mathrm{a}}$ & $10.89^{\mathrm{a}}$ & $10.56^{\mathrm{b}}$ & $7.06^{\mathrm{c}}$ \\
\hline \multirow{3}{*}{100} & 0 & $2.39^{\mathrm{b}}$ & $1.61^{\mathrm{c}}$ & $1.88^{\mathrm{b}}$ & $3.06^{\mathrm{de}}$ & $4.55^{\mathrm{b}}$ & $3.44^{\mathrm{b}}$ & $3.11^{\mathrm{c}}$ & $6.78^{\mathrm{c}}$ \\
& 50 & $2.22^{\mathrm{b}}$ & $2.11^{\mathrm{c}}$ & $1.39^{\mathrm{b}}$ & $2.45^{\mathrm{e}}$ & $3.89^{\mathrm{b}}$ & $3.34^{\mathrm{b}}$ & $2.00^{\mathrm{c}}$ & $3.00^{\mathrm{d}}$ \\
& 100 & $3.19^{\mathrm{b}}$ & $2.11^{\mathrm{c}}$ & $1.61^{\mathrm{b}}$ & $2.39^{\mathrm{e}}$ & $5.22^{\mathrm{b}}$ & $5.00^{\mathrm{b}}$ & $3.28^{\mathrm{c}}$ & $3.33^{\mathrm{d}}$ \\
& 150 & $2.64^{\mathrm{b}}$ & $2.45^{\mathrm{c}}$ & $2.06^{\mathrm{b}}$ & $2.61^{\mathrm{e}}$ & $4.50^{\mathrm{b}}$ & $5.78^{\mathrm{b}}$ & $3.61^{\mathrm{c}}$ & $3.94^{\mathrm{d}}$ \\
\hline
\end{tabular}

Note: Means followed by the same letter at the same column is not significantly different according to Duncan Multiple Range Test $5 \%$

intensity, the increase of paclobutrazol concentration tend to increase tuber dry weight. Meanwhile under full sunlight intensity, paclobutrazol application increased tuber dry weight up to 100 ppm (Fig. 1b).

Ghosh et al. (2002) stated that shading decreased yield dry matter significantly. As the level of shade increased, the reduction in yield dry matter also increased. This might be caused by the reduction of nitrate reductase enzyme that decrease with the decrease of light intensity. Nitrate reductase is a limited enzyme in nitrogen assimilation, correlated with plant growth and regulation and in some plant correlated positively with the yield. The decrease of tuber production due to reduced light intensity has also reported by Oswald et al. (1995); Parman (2010); and Lestari et al. (2012).

Banon et al. (2002) stated that the use of paclobutrazol could increase tuber dry weight. Paclobutrazol inhibit gibberellin formation and makes the tuber become the biggest and strongest photosynthesis sink.
Besides plant yield, secondary metabolites become an important consideration in medicinal plant production such as rodent tuber. Nobakht et al. (2008) stated that major secondary metabolites on rodent tuber are alkaloids and flavonoids (part of phenolic). Mohan et al. (2008a) reported that total phenolic content of rodent from methanol extract (5.69 \pm 0.15 GAE mg g ${ }^{-1}$ extract) was superior compared with dichloromethane, ethyl acetate and hexane extract, while total phenolic extract on tuber $5.21 \mathrm{GAE} \mathrm{\textrm {mg } \mathrm { g } ^ { - 1 }}$ extract (Mohan et al. 2008b).

The nature and number of secondary compounds produced by the plant species during its development depends on internal and environmental factors, which can act directly on the synthesis of secondary metabolites, or indirectly increase or decrease the biomass of plants (Gouinguene \& Turlings 2002). Therefore, it is assumed that light intensity and growth retardant may affect the quantity and quality of rodent tuber secondary metabolites and may also increase or degrade plant biomass. 

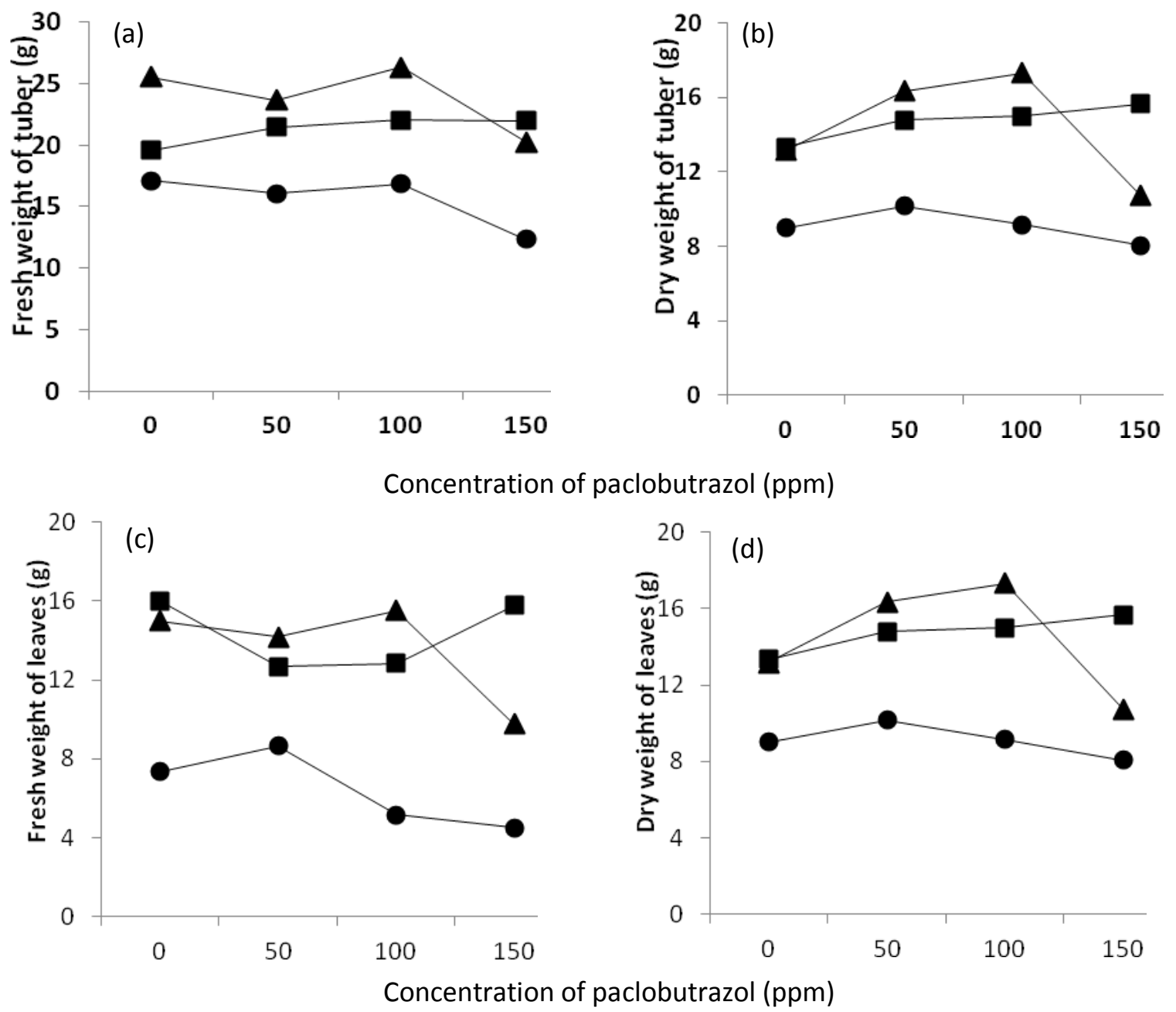

Figure 1. Effect of interaction between light intensity and paclobutrazol concentration to (a) tuber fresh weight, (b) tuber dry weight, (c) leaves fresh weight and (d) leaves dry weight. Each point represents the mean of nine observations. $\mathbf{A}=$ light intensity $100 \%$; $\mathbf{\square}$ light intensity $55 \%$; $=$ light intensity $35 \%$.

\section{CONCLUSIONS}

Rodent tuber under 35\% light intensity showed the lowest dry weight in all paclobutrazol treatments. Full light intensity showed the highest dry weight in all paclobutrazol treatments. However, the dry weight decreasing at $150 \mathrm{ppm}$ paclobutrazol. Therefore, it is recommended to cultivate rodent tuber under full light intensity or $55 \%$ light intensity at 100 ppm paclobutrazol.

\section{REFERENCES}

Banon S, Gonzales A, Cano EA, Franco JA, Fernandez JA. 2002. Growth, development and color response of potted Dianthus caryophyllus cv
Mondriaan to paclobutrazol treatment. Scientia Horticulturae. 94(3-4):371-377.

Cathey HM. 1975. Comparative plant growth-retarding activities of ancymidol with ACPC, phosfon, chlormequat, and SADH on ornamental plant species. Horticultural Science. 10(3):204-215.

Chaney WR. 2005. Growth Retardants: A promising tool for managing urban trees. http://www.extension.purdue.edu/extmedia/f $\mathrm{nr} /$ fnr-252-w.pdf. [30 Juli 2015]

Choo CY, Chan KL, Takeya K, Itokawa H. 2001. Cytotoxic activity of Typhonium flagelliforme (Araceae). Phytotherapy Research. 15:260-262. 
Da'i M, Fiveri A, Meiyanto E. 2007. Efek sitotoksik ekstrak tanaman keladi tikus (Typhonum divaricatum (L.) terhadap sel HeLa. Jurnal Farmasi Indonesia. 3(4):163-167.

Clifford DR, Lenton JR. 1979. Modes of action of growth retardant. p 1-14. In: Recent development in the use of plant growth retardants. Proceeding of a Symposium by the Society of Chemical Industry and British Plant Growth Regulator Group. $29^{\text {th }}$ October 1979. London (UK): Long Ashton.

Djukri. 2003. Efek fisiologis naungan buatan pada tanaman talas (Colocasia esculenta (L.) Schott). Jurnal Pendidikan Matematika dan Sains. 2:114-120.

Esmaielpour B, Hokmalipour S, Jalilvand P, Salimi G. 2011. The investigation of paclobutrazol effects on growth and yield of two potato (Solanum tuberosum) cultivars under different plant density. Journal of Food, Agriculture and Environment. 9(3):289-294.

Flexas J, Bota J, Galmés J, Medrano H, Ribas-Carbó. 2006. Keeping a positive carbon balance under adverse conditions: responses of photosynthesis and respiration to water stress. Physiologia Plantarum. 127:343-352.

Gardner FP, Pearce RB, Mitchell RL. 1991. Fisiologi Tanaman Budidaya. Terjemahan Susilo $\mathrm{H}$. Jakarta (ID): UI Press.

Geng H, Wang J, Dong L, Meng P, Zhang J, Yang S. 2013. Effects of different light intensities on the photosynthesis and the tubers yield of Pinellia ternata (Thunb.) Breit. Journal of Agricultural Science and Applications. 2(1):51-56.

Ghosh SC, Asanuma KI, Kusutani A, Toyota M. 2002. Effect of shading on dry matter production, yield and nitrate reductase activity of potato under two levels of spacing. Environment Control in Biology. 40(3):259-268.

Gomez KA, Gomez AA. 1995. Prosedur Statistik untuk Penelitian Pertanian. Jakarta (ID): UI-Press.

Gouinguene SP, Turlings TCJ. 2002. The effects of abiotic factors on induced volatile emissions in corn plants. Plant Physiology. 129:1296-1307.

Huang P, Karagianis G, Waterman PG. 2004. Chemical coinalnstituents from Typhonium flagelliforme. Journal of Chinese Medicinal Materials. 27:173175.
Kozak D. 2002. The effect of growth retardants on induction and development of Gloriosa rothschildiana O'Brien tubers in vitro. Acta Horticulturae. 570:345-349.

Lai CS, Mas RH, Nair NK, Mansor SM, Navaratnam V. 2010. Chemical constituents and in vitro anticancer of Typhonium flagelliforme (Araceae). Journal of Ethnopharmacology. 127(2):486-494.

Lestari P, Utami NW, Wawo AH. 2012. Adaptasi aksesi kentang hitam (Plecranthus rotundifolius [Poir.] Spreng) terhadap berbagai intensitas cahaya. Berita Biologi. 11(3):351-358.

Mohan S, Abdul AB, Wahab SIA, AI-Zubairi AS, Elhassan MM, Yousif M. 2008a. Investigations of antioxidant and antibacterial activities of Typhonium flagelliforme (Lodd.) Blume leaves. Research Journal of Pharmacology. 2(4):47-51.

Mohan S, Abdul AB, Wahab SIA, Al-Zubairi AS, Elhassan MM, Yousif M. 2008b. Antibacterial and antioxidant activities of Typhonium flagelliforme (Lodd.) Blume tuber. American Journal of Biochemistry and Biotechnology. 4(4):402-407.

Neoh CK. 1992. Typhonium divaricatum (rodent tuber): a promising local plant in the fight against cancer. Medical Journal of Malaysia. 47(1):8688.

Nobakht GM, Kadir MA, Stanslas J. 2010. Analysis of preliminary phytochemical screening of Typhonium flagelliforme. African Journal of Biotechnology. 9:1655-1657.

Oswald A, Alkamper J, Midmore DJ. 1995. The effect of different shade levels on growth and tuber yield of sweet potato: II. Tuber yield. Journal of Agronomy and Crop Science. 175:29-40

Parman S. 2010. Pengaruh intensitas cahaya terhadap produksi umbi tanaman lobak (Raphanus sativus L.). Buletin Anatomi dan Fisiologi. 18I(2):29-38.

Putra A, Tjahjono, Winarto. 2011. Ekstrak keladi tikus (Typhonium flagelliforme) fraksi diklorometanolik dan ekspresi Caspase-3 dan p21 Cell-Line kanker payudara MCF-7. Media Medika Indonesiana. 45(2):95-104.

Putra A, Tjahjono, Winarto. 2012. Efektivitas ekstrak umbi Typhonium flagelliforme fraksi diklorometanolik dalam menghambat proliferasi sel MCF-7 kanker payudara. Journal 
of the Indonesian Medical Association. 62:1015.

Salisbury FB, Ross CW. 1992. Fisiologi Tumbuhan Jilid 2. Bandung (ID): Penerbit ITB.

Sambeka F, Runtunuwu SD, Rogi JEX. 2012. Efektifitas waktu pemberian dan konsentrasi paclobutrazol terhadap pertumbuhan dan hasil kentang (Solanum tuberosum L.) varietas Supejohn. Eugenia. 18(2):126-133.

Sinclair J, Muchow. 1999. Light adaptation/acclimation of photosynthesis and the regulat ion of Ribulose-1,5-Biphosphate Carboxylase activity in sun and shade plants. Plant Physiology. 91(1):379-386.

Sunarlim N, Minantyorini, Zuraida N, Mariska I, Hanarida I, Kosmiatin M, Adil WH, Kurnawan H, Tamunan IR. 2000. Pelestarian plasma nutfah ubi-ubian secara in vitro. Bogor (ID): Laporan Hasil Penelitian Baltbio.

Syahid SF. 2008. Keragaman morfologi, pertumbuhan, produksi, mutu dan fitokimia keladi tikus (Typhonium flagelliforme Lodd.) Blume asal variasi somaklonal. Jurnal Penelitian Tanaman Industri. 14:113-118.

Tanis SR, McCullough DG, Bregg BM. 2015. Effects of paclobutrazol and fertilizer on the physiology, growth and biomass allocation of three Fraxinus species. Urban Forestry \& Urban Greening. 14:590-598.

Tekalign T, Hammes PS. 2005. Growth and Biomass production in potato grown in the hot tropics as influenced by paclobutrazol. Plant Growth Regulator. 45:37-46.

Yunahara F, Wahyudi PS, Sumaryono W, Hanafi M. 2012. Flavonoid glycoside from the ethyl acetate extracts of keladi tikus Typhonium flagelliforme (Lodd) Blume leaves. Asian Journal of Natural and Applied Science. 1(4):1621.

Zhong Z, Zhou G, Chen X, Huang P. 2001. Pharmacological study on the extracts from Typhonium flagelliforme Blume. Journal of Chinese Medicinal Materials. 24(10):735-738. 